\title{
Utilization of Reproductive and Child Health Services and Client Satisfaction under Different Level of Health Facilities
}

\author{
Vaibhav Singh ${ }^{1}$, Harshita Baranwal ${ }^{2}$, Dhiraj Kumar Srivastava ${ }^{3}$, Pankaj Kumar Jain ${ }^{4}$, Debora J Mathew ${ }^{5}$, Saurabh \\ Saxena ${ }^{6}$
}

${ }^{1}$ Post Graduate, Department of Community Medicine, Uttar Pradesh University of Medical Sciences, Saifai, Etawah, Uttar Pradesh; ${ }^{2}$ Senior Resident, Department of Pathology, Dr. Ram Manohar Lohia Institute of Medical Sciences, Lucknow, Uttar Pradesh; ${ }^{3}$ Associate Professor, Department of Community Medicine, Uttar Pradesh University of Medical Sciences, Saifai, Etawah, Uttar Pradesh; ${ }^{4}$ Professor and Head, Department of Community Medicine, Uttar Pradesh University of Medical Sciences, Saifai, Etawah, Uttar Pradesh; ${ }^{5}$ Post Graduate, Department of Community Medicine, Uttar Pradesh University of Medical Sciences, Saifai, Etawah, Uttar Pradesh; ${ }^{6}$ Post Graduate, Department of Community Medicine, Uttar Pradesh University of Medical Sciences, Saifai, Etawah, Uttar Pradesh

\begin{tabular}{|c|c|c|c|c|c|c|c|c|}
\hline Abstract & Introduction & Methodology & Results & Conclusion & References & Citation & \multicolumn{2}{|c|}{ Tables / Figures } \\
\hline \multicolumn{9}{|c|}{ Corresponding Author } \\
\hline \multicolumn{8}{|c|}{$\begin{array}{l}\text { Dr. Dhiraj Kumar Srivastava, Associate Professor, Department of Community Medicine, Uttar Pradesh } \\
\text { University of Medical Sciences, Saifai, Etawah, Uttar Pradesh } \\
\text { E Mail ID: dhirajk78sri@yahoo.co.in }\end{array}$} & 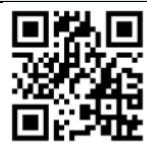 \\
\hline
\end{tabular}

\section{Citation}

Singh V, Baranwal H, Srivastava DK, Jain PK, Mathew DJ, Saxena S.Utilization of Reproductive and Child Health Services and Client Satisfaction under Different Level of Health Facilities. Indian J Comm Health. 2020;32(1):82-86.

Source of Funding: Nil Conflict of Interest: None declared

Article Cycle

Received: 11/02/2020; Revision: 20/02/2020; Accepted: 05/03/2020; Published:31/03/2020

This work is licensed under a Creative Commons Attribution 4.0 International License.

\section{Abstract}

Background: The utilization of any social services, including health services, has never been equitably distributed throughout society. People with access to the facilities are generally found to make greater use of them than people who have neither knowledge nor access to the facilities. Objective: To study the utilization pattern of RCH services, to identify factors influencing the utilization of RCH services in district Etawah and to describe level of client satisfaction about the various RCH services provided by Health Facility. Methods: This was a cross sectional study conducted in two blocks of Etawah i.e., Basrehar and Jaswant Nagar. Purposive sampling method was used and 260 participants were interviewed during the study period i.e., from May 2018 to April 2019.All the antenatal mothers and mothers with child up to 24 months attending OPD of selected health facility were included in the study. Result: Mean age of participants was found to be $24.9 \pm 3.6$ years. The proportion of previous delivery that was institutional was found to be $71.7 \%$ where as $28.3 \%$ had previous home delivery. Most common place for institutional delivery was found to be $\mathrm{CHC}$. Conclusion: Utilization of RCH services were found to be not adequate in the study.

\section{Keywords}

Cross Sectional Study; Health Facility; Client Satisfaction

\section{Introduction}

Maternal complications and poor perinatal outcome were associated with non utilization of antenatal and delivery care services. Poorer outcomes were seen in unbooked than booked pregnant females.(1)

In lower and middle-income countries, less than $50 \%$ of all pregnant women have a minimum of four antenatal care visits.(2) Cost, distance, viewpoint of health providers, and other factors put the secondary care and private sector facilities inaccessible to most of the poor urban residents. The health of the urban poor is considerably worse off than the urban middle and high income groups and is perhaps even worse than the rural population.(3)Socioeconomic factors have often been used as revelatory factors for low utilization of $\mathrm{RCH}$ services. The socioeconomic factors are related to socioeconomic factors, and often in the scarcity of good data, it is very difficult to explain the poor utilization of $\mathrm{RCH}$ services.(4)

\section{Aims \& Objectives}

1. To study the utilization pattern of Reproductive and child health services 
2. To identify the factors influencing the utilization of Reproductive and Child Health services at various levels of health services in district Etawah

3. To describe level of client satisfaction about the various Reproductive and child health services provided by different health facilities in Etawah

\section{Material \& Methods}

Study Type: A cross sectional study

Study population: Pregnant women and women with child upto 24 months in the 2 blocks of District Etawah.

Study area: Two blocks of District Etawah.

Study Duration: One and half years (Jan 2018 to July 2019)

Sampling technique: Purposive sampling

Inclusion Criteria: All the selected pregnant women and women attending $\mathrm{PHC}, \mathrm{CHC}$ and Subcentre OPD in the selected block whose child was less than 24 months and giving consent for the participation in the study for exit OPD interview

Exclusion Criteria: Women not giving consent for the participation in the study for exit OPD interview

\section{Methodology}

There are 8 blocks in District Etawah. Of these, 2 blocks of Basrehar and Jaswant Nagar were selected randomly. In each of the selected block, one block $\mathrm{CHC}$ was included, and 2 PHCs and 3 subcentres were selected randomly. In Basrehar block we conducted exit OPD interview at $\mathrm{CHC}$ Basrehar on every Monday. So there were total 12 visit at $\mathrm{CHC}$ Basrehar during the period of three months. Similarily for PHC, exit interview were conducted on every Tuesday of a week. So, we had a total of 6 visit at each PHC. For Subcentre we had exit OPD interview on every Wednesday of week, so there were total 4 visit at every selected Subcentre. A total of 130 participants were interviewed in Block Basrehar during 3 months of study at different health care facility. Out of 130 participants, 100 participants were from $\mathrm{CHC}, 20$ from $\mathrm{PHC}$ and 10 were from subcentre. Only 130 participants were interviewed during 3 months due to lack of time and manpower.

After the study period of three month in the Basrehar we conducted our study in Jaswantnagar block. To ensure comparability between the two blocks we interviewed same number of participants from $\mathrm{CHC}, \mathrm{PHC}$ and subcentre of Jaswantnagari.e, a total of 130 participants, out of which 100 from $\mathrm{CHC}, 20$ from $\mathrm{PHC}$ and 10 from subcentre were interviewed. After interviewing the required participants in the $\mathrm{CHC}, \mathrm{PHC}$ and Jaswantnagar block we stopped there only and didn't had any further interview at that health facility.

On the day of exit interview every 10th patient who was registered for ANC was selected from register, if she refused next female was taken for interview. Beside this, mother attending paediatric OPD were also interviewed. If participant of both groups were available preference was given to pregnant mothers as they were current utilizers. In the selected PHC same procedure was done. In
Subcentre all the pregnant female and women up to child less than 24 months interviewed A pretested semi structured Questionnaire containing both open and closed ended question were used. Information were gathered under the following $\mathrm{RCH}$ services:

- Institutional delivery

- Contraception services

- STI treatment services

- Child care services like diarrheal treatment

- Vaccination services

Ethical approval- The study was approved by the Institutional Ethics Committee i.e,UPUMSSaifai on 13-082018 (Ethical clearance certificate no.-45/2018)

Consent - Written Consent was taken prior to the interview in the form attached with the questionnaire.

Data Analysis: The data collected were encoded into Microsoft Excel sheet and analysed using SPSS version 23. Data was analyzed using appropriate statistical tests like frequency, percentage mean, chisquare and logistic regression. Charts like bar charts and pie charts were for presentation of data

\section{Results}

In the present study a total of 260 participants were interviewed out of which 20 were primigravida (i.e, those who were currently pregnant and had no previous delivery or abortion) and 240 were primipara, multigravida and multipara. The most common age group of participants was between 25 to 30 years i.e, $46.9 \%$. Mean age was found to be $24.9 \pm 3.6$ years. (Table 1 ) Majority of the females practiced exclusive breast feeding (66.60\%). On doing analysis of question related to vaccination it was noted that only $77 \%$ of the children upto the age of 2 years had received single dose of any vaccine registered under national immunization schedule (this does not include vaccine during pulse polio immunization). Maximum participants visited $\mathrm{PHC}$ for their child's diarrhoeal treatment (47.9\%) followed by $\mathrm{CHC}$ (43.8\%). ORS was prescribed to 53 children out of 73 children (72.6\%) who took treatment for diarrhoea. Out of 233 participants who needed services for STI, only 53 (21.5\%) seek treatment, while 180 (69.2\%) did not seek any treatment.

\section{Discussion}

Our study revealed that $28.3 \%$ participants had home delivery and $71.7 \%$ had institutional delivery. Majority of the institutional delivery were conducted at $\mathrm{CHC}$ (85.4\%) followed by PHC.

Majority of the other studies had showed proportion of institutional delivery less than our study. (5-10) However, some studies had shown higher proportion of institutional deliveries like Kotresh and Kumar $P(9)$ had $93.5 \%$ and Dabade K J(10) et al had $90.3 \%$ of institutional deliveries, this difference could be attributed to different study setting. 
This study revealed that 131 participants (50.4\%) ever used any of the contraception while 129 participants (49.6\%) never used any contraception, and most commonly used contraceptive was condom (39\%) followed by OCP (34\%). Study conducted by Banerji B et al(11) resulted prevalence of $68.5 \%$ of contraception services utilization. Malathi et al (12) study showed family planning services utilization rate as $77 \%$. In their study also the most common contraception was condom (38.6\%). The present study found the proportion of exclusive breastfeeding as $67 \%$. Bhavsar et al(13) also got the similar prevalence of exclusive breastfeeding of $66 \%$ in their study.

This study revealed that there was significant association between place of delivery and exclusive breast feeding(pvalue-0.001), as it was found more common in institutional deliveries (86.5\%) as compared to home deliveries (13.5\%). This study shows significant association between literacy level and exclusive breast feeding (pvalue-0.001). As the literacy level increases practice of exclusive breastfeeding also increases. Association was also found between socioeconomic class and exclusive breast feeding (pvalue-0.001), exclusive breastfeeding found more common in higher monthly per capita income group participants While the study conducted by Bhavsar et al(13) didn't found any association between socioeconomic class and exclusive breast feeding( $p$ value - 0.949), that may be due to different study setting. This study revealed significant association between religion and place of delivery. Institutional delivery was more common in Hindu religion as compared to Muslim. Other studies didn't find these associations that were found in our study, that may be due to the fact that other study didn't tried to relate these variables with the different $\mathrm{RCH}$ services.

\section{Conclusion}

The proportion of previous delivery that was institutional was found to be $\mathbf{7 1 . 7 \%}$ where as $28.3 \%$ had previous home delivery. Most common place for institutional delivery was found to be $\mathrm{CHC}$. The study found significant association of exclusive breastfeeding and contraception usage with the monthly per capita income, education level and place of delivery. Majority of the participants were moderately satisfied with $\mathrm{RCH}$ services received by them.

\section{Recommendation}

Promotion of female literacy is required to improve utilization of maternal health services as it was highly associated with usage of $\mathrm{RCH}$ services.

\section{Limitation of the study}

The total number of participants were only 260 , so generalizability of the study is less.

\section{Relevance of the study}

This study revealed the current utilization rate of different $\mathrm{RCH}$ services and factors affecting it in Etawah district

\section{Authors Contribution}

All authors have contributed equally.

\section{References}

1. A.T.Owolabi,A.O.Fatusi,O.Kuti,A.Adeyemi,S.O.Faturoti,andP.O.Obi ajuwa,"Maternalcomplications and perinatal outcomes in booked and unbooked Nigerian mothers," Singapore Medical Journal,vol.49,no.7,pp.526-531,2008

2. Maternal mortality," Fact Sheet 348 , Media centre, World health organisation, 2010, http://www.who.int/mediacentre/ factsheets/fs348/en/index.html.

3. K.Yadav,S.V.Nikhil,andC.S.Pandav, “Urbanization and health challenges: need to fast track launch of the national urban health mission,"Indian Journal of Community Medicine,vol.36, no.1,p.37,201

4. A. Singh and A. K. Arora, "The changing profile of pregnant women and quality of antenatal care in rural North India," Indian Journal of Community Medicine, vol. 32, pp. 135-136, 2007.

5. Bhaisare K, Rao D, Khakase G. Study of utilization of antenatal care services in tribal area of Thane district. Int J Reprod Contracept Obstet Gynecol. 2015;4(2):378.

6. Pahwa $\mathrm{P}$, Sood A. Existing practices and barriers to access of $\mathrm{MCH}$ services - a case study of residential urban slums of district Mohali, Punjab, India.Global journal of medicine and public health Vol. 2, No. $42013: 8$.

7. Agarwal N, Galhotra A, Swami HM. A study on coverage utilization and quality of maternal care services.National journal of community medicine 2011. 2(1):5.

8. Sadhna S, Kajal J, Debabratta R, Kishore S, Gupta S, Kandpal S. Utilisation of maternal health services and its predictors in slum population. Acta Med Int. 2016;3(1):56

9. Kotresh $M$, Kumar P. Determinants of Use of Maternal Health Services in Rural Field Practice area of Basaveshwara Medical College, Chitradurga: A Cross sectional Study.Journal of Preventive Medicine and Holistic Health, July-December 2015;1(2):59-66.

10. Dabade KJ, Dabade SK, Khadilkar HA. A study on utilization of maternal health care services in rural area of Aurangabad district, Maharashtra. National Journal of Community Medicine Volume 4 Issue 4 Oct-Dec 2013 4(4):5.

11. Banerjee B.A qualitative analysis of maternal and child health services of an urban health centre, by assessing client perception in terms of awareness, satisfaction and service utilization. Indian Journal of Community Medicine Vol. XXVIII, No.4, Oct.-Dec., 2003:153-156

12. Karkada S. A study on the awareness of utilization of reproductive and child health $(\mathrm{RCH})$ services in the selected villages of Udupi District, Karnataka.International Journal of Nursing Education. 2010;2(2):6.

13. Bhavsar S, Mehta J, Gohel A, Lodha N, Parmar D. Assessment of utilization of child health services (under RCH program) and incorrect practices related to perinatal events in Jamnagar district, Gujarat, India. Int J Res Med Sci. 2015;3206-10.

\section{Tables}

TABLE 1 PARTICIPANTS ACCORDING TO SOCIO-DEMOGRAPHIC CHARACTERISTICS ( $\mathrm{N}=260)$

\begin{tabular}{|c|c|c|c|}
\hline Characteristics & Category & Frequency & Percentage (\%) \\
\hline \multirow{2}{*}{ Age } & $<20$ years & 5 & 1.9 \\
\cline { 2 - 4 } & Between 20 to 24years & 115 & 44.2 \\
\cline { 2 - 4 } & Between 25 to 30 years & 122 & 46.9 \\
\hline
\end{tabular}




\begin{tabular}{|c|c|c|c|}
\hline & $>30$ years & 18 & 6.9 \\
\hline & Total & 260 & 100 \\
\hline \multirow[t]{3}{*}{ Religion } & Hindu & 247 & 95.0 \\
\hline & Muslim & 13 & 5.0 \\
\hline & Total & 260 & 100 \\
\hline \multirow[t]{7}{*}{ Education Up To } & Illiterate & 36 & 13.8 \\
\hline & Primary & 89 & 34.2 \\
\hline & Secondary & 52 & 20.0 \\
\hline & Higher Secondary & 56 & 21.5 \\
\hline & Graduate & 17 & 6.5 \\
\hline & Post graduate & 10 & 3.8 \\
\hline & Total & 260 & 100 \\
\hline \multirow[t]{2}{*}{ Monthly Per Capita Income } & $<2000 \mathrm{Rs}$ & 166 & 63.8 \\
\hline & $\geq 2000 \mathrm{Rs}$ & 94 & 36.2 \\
\hline \multicolumn{2}{|c|}{ Total } & 260 & 100 \\
\hline
\end{tabular}

TABLE 2 DISTRIBUTION OF PARTICIPANTS BASED ON THE OF PLACE OF LAST DELIVERY OF BABY (N=240)

\begin{tabular}{|c|c|c|}
\hline Place & Frequency & Percent \\
\hline Home & 68 & 28.3 \\
\hline Institutional & 172 & 71.7 \\
\hline Total & 240 & 100 \\
\hline
\end{tabular}

TABLE 3 ASSOCIATION BETWEEN PLACE OF DELIVERY AND EXCLUSIVE BREAST FEEDING

\begin{tabular}{|c|c|c|c|c|} 
Exclusive breast feeding & \multicolumn{2}{c}{ Place of delivery } & \multicolumn{2}{c}{ Total } \\
\cline { 1 - 3 } & Home & Institutional & $155(100 \%)$ & $<0.001$ \\
Yes & $21(13.5 \%)$ & $134(86.5 \%)$ & $85(100 \%)$ & $\chi^{2}=47.114$ \\
\hline No & $47(55.2 \%)$ & $38(44.8 \%)$ & $240(100 \%)$ & \\
\hline Total & $68(28.3 \%)$ & $172(71.7 \%)$ & \\
\hline
\end{tabular}

TABLE 4 ASSOCIATION BETWEEN MONTHLY PER CAPITA INCOME AND CONTRACEPTION USE

\begin{tabular}{|c|c|c|c|c|}
\hline \multirow[t]{2}{*}{ Contraception use } & \multicolumn{2}{|c|}{ Monthly per capita income } & \multirow[t]{2}{*}{ Total } & \multirow[t]{2}{*}{ P value } \\
\hline & $\leq 2000$ & $>2000$ & & \\
\hline Yes & $60(48.7 \%)$ & $63(51.3 \%)$ & $123(100 \%)$ & \multirow{3}{*}{$\begin{array}{c}0.001 \\
\chi^{2}=75.223\end{array}$} \\
\hline No & $93(79.4 \%)$ & $24(20.6 \%)$ & $117(100 \%)$ & \\
\hline Total & $153(63.7 \%)$ & $87(36.3 \%)$ & $240(100 \%)$ & \\
\hline
\end{tabular}

TABLE 5 ASSOCIATION BETWEEN RELIGION AND PLACE OF DELIVERY

\begin{tabular}{|c|c|c|c|c|}
\hline \multirow[t]{2}{*}{ Place of delivery } & \multicolumn{2}{|c|}{ Religion } & \multirow[t]{2}{*}{ Total } & \multirow[t]{2}{*}{$P$ value } \\
\hline & Hindu & Muslim & & \\
\hline Home & $60(88.2 \%)$ & $8(11.8 \%)$ & 68 (100\%) & \multirow{3}{*}{$\begin{array}{c}0.011^{*} \\
\chi^{2}=7.463\end{array}$} \\
\hline Institutional & $167(97 \%)$ & $5(3 \%)$ & $172(100 \%)$ & \\
\hline Total & 227 (94.5\%) & 13 (5.5\%) & 240 (100\%) & \\
\hline
\end{tabular}

TABLE 6 LOGISTIC REGRESSION ANALYSIS OF EXCLUSIVE BREAST FEEDING WITH DIFFERENT COVARIATES

\begin{tabular}{|c|c|c|c|c|c|c|c|}
\hline & & \multicolumn{3}{|c|}{ Univariate Analysis } & \multicolumn{3}{|c|}{ Multivariate Analysis } \\
\hline Covariates & Category & Crude odds ratio & C.I (95\%) & $p$ value & Adjusted odds ratio & C.I (95\%) & $p$ value \\
\hline \multirow{2}{*}{$\begin{array}{l}\text { Per capita } \\
\text { income }\end{array}$} & $<2000$ & 1 & \multirow{2}{*}{$\begin{array}{l}6.908- \\
21.037\end{array}$} & \multirow[t]{2}{*}{$<0.001$} & 1 & \multirow{2}{*}{$\begin{array}{l}5.191- \\
25.207\end{array}$} & \multirow[t]{2}{*}{$<0.001$} \\
\hline & $\geq 2000$ & 13.222 & & & 10.450 & & \\
\hline \multirow{2}{*}{$\begin{array}{l}\text { Place of } \\
\text { delivery }\end{array}$} & Home & 1 & \multirow{2}{*}{$\begin{array}{l}4.212- \\
14.789\end{array}$} & \multirow[t]{2}{*}{$<0.001$} & 1 & \multirow{2}{*}{$\begin{array}{l}2.822- \\
12.170\end{array}$} & \multirow[t]{2}{*}{$<0.001$} \\
\hline & institutional & 7.892 & & & 5.860 & & \\
\hline \multirow[t]{2}{*}{ Religion } & Hindu & 1 & \multirow{2}{*}{$\begin{array}{c}0.040- \\
0.554\end{array}$} & \multirow[t]{2}{*}{0.005} & 1 & \multirow{2}{*}{$\begin{array}{c}0.128- \\
2.326\end{array}$} & \multirow[t]{2}{*}{0.413} \\
\hline & Muslim & 0.148 & & & 0.546 & & \\
\hline
\end{tabular}

TABLE 7 LOGISTIC REGRESSION ANALYSIS OF CONTRACEPTION USAGE WITH DIFFERENT COVARIATES

\begin{tabular}{|c|c|c|c|c|c|c|c|}
\hline & & \multicolumn{3}{|c|}{ Univariate Analysis } & \multicolumn{3}{|c|}{ Multivariate Analysis } \\
\hline Covariates & Category & Crude odds ratio & C.I & $P$ value & Adjusted odds ratio & C.I & $P$ value \\
\hline \multirow[t]{2}{*}{ Per capita income } & $<2000$ & 1 & \multirow{2}{*}{$\begin{array}{l}2.770- \\
8.037\end{array}$} & \multirow[t]{2}{*}{0.002} & 1 & \multirow{2}{*}{$\begin{array}{l}5.191- \\
25.207\end{array}$} & \multirow[t]{2}{*}{$<0.001$} \\
\hline & $\geq 2000$ & 4.718 & & & 4.854 & & \\
\hline \multirow[t]{2}{*}{ Place of delivery } & Home & 1 & \multirow{2}{*}{$\begin{array}{c}1.422- \\
4.558\end{array}$} & \multirow[t]{2}{*}{0.002} & 1 & \multirow{2}{*}{$\begin{array}{c}0.762- \\
2.837\end{array}$} & \multirow[t]{2}{*}{0.250} \\
\hline & institutional & 2.546 & & & 1.471 & & \\
\hline \multirow[t]{2}{*}{ Religion } & Hindu & 1 & \multirow{2}{*}{$\begin{array}{c}0.009- \\
0.576\end{array}$} & \multirow[t]{2}{*}{0.013} & 1 & \multirow{2}{*}{$\begin{array}{c}0.020- \\
1.359\end{array}$} & \multirow[t]{2}{*}{0.094} \\
\hline & Muslim & 0.074 & & & 0.166 & & \\
\hline
\end{tabular}




\section{Figures}

FIGURE 1 COLUMN GRAPH SHOWING THE PLACE OF INSTITUTIONAL DELIVERY OF STUDY PARTICIPANTS

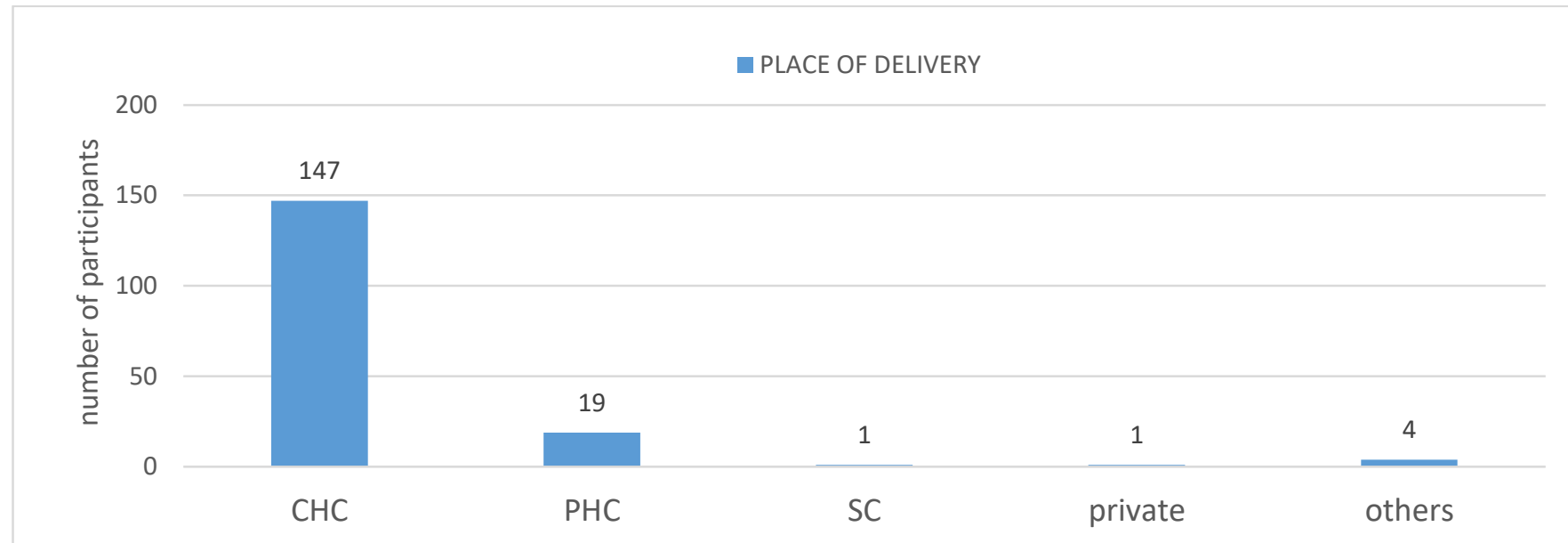

FIGURE 2 COLUMN GRAPH SHOWING THE DISTRIBUTION OF TYPE OF CONTRACEPTION USED BY PARTICIPANT

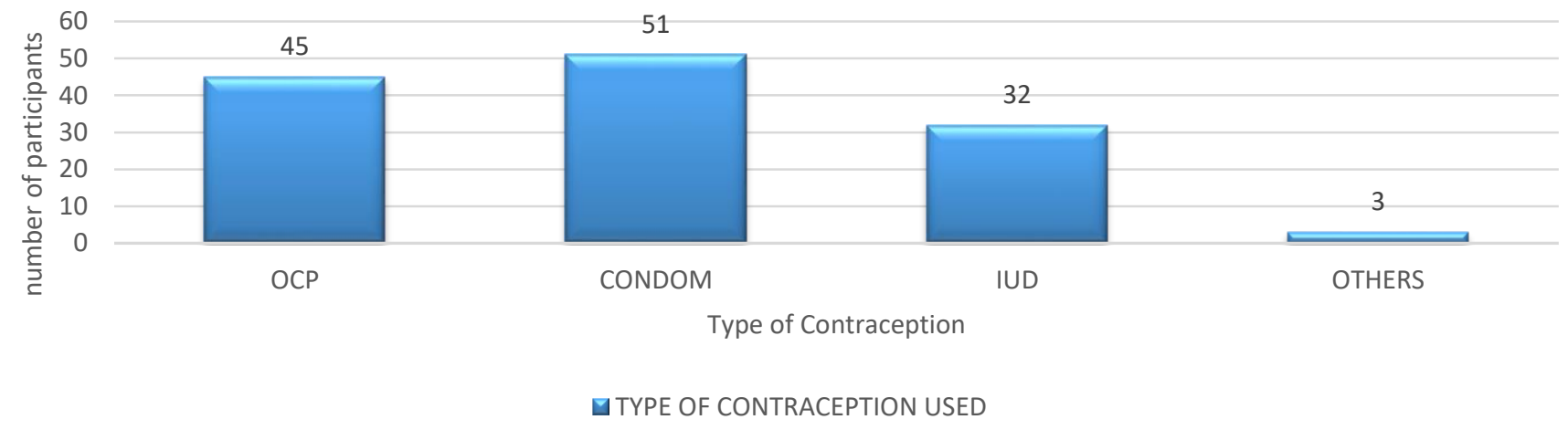

FIGURE 3 PIE CHART SHOWING THE DISTRIBUTION OF SATISFACTION LEVEL OF PARTICIPANTS WITH THE QUALITY OF OVERALL SERVICES AT CENTRE

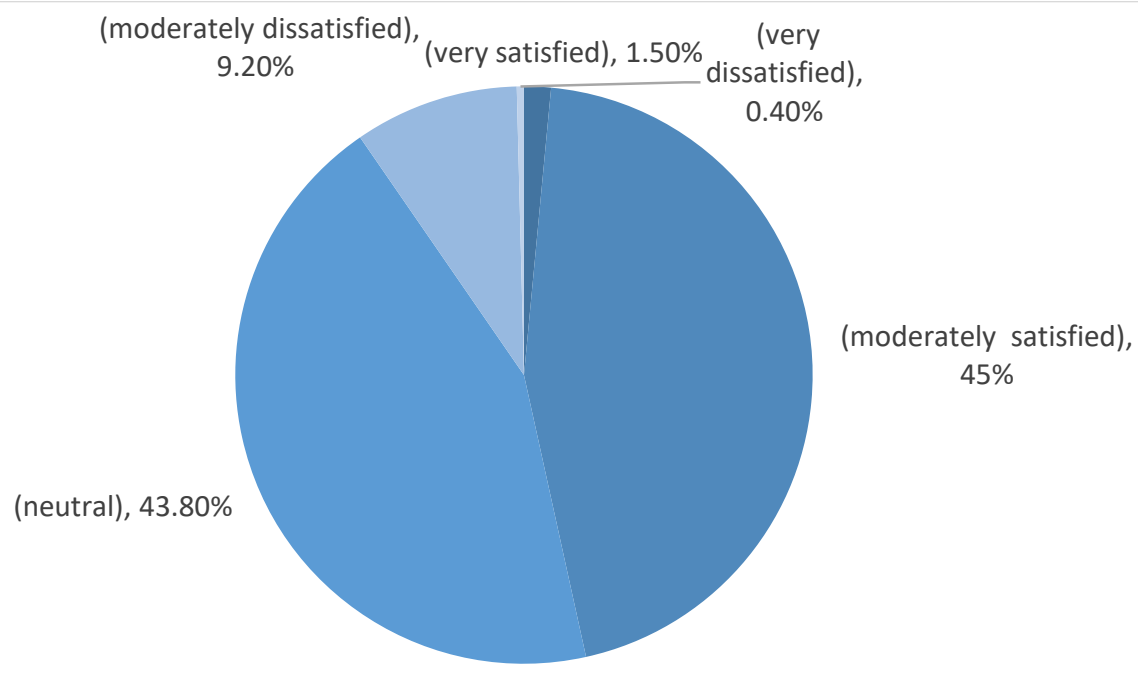

$\square$ (very satisfied) $\square$ (moderately satisfied) $\square$ (neutral) $\square$ (moderately dissatisfied) $\square$ (very dissatisfied) 